\title{
Bioassay Studies for Testing Toxicity of Novel Insecticides against Spodoptera litura (Fabricius.)
}

\author{
Sashanka Sekhar Dash*, M. Lava Kumar Reddy, G. Sridevi, Bharathi N. Bhat
}

Jayashankar Telangana State Agricultural University, Hyderabad-500030, Telangana, India

*Corresponding author

\section{A B S T R A C T}

\begin{tabular}{|l|}
\hline Ke y w o r d s \\
Insecticides, \\
$\begin{array}{l}\text { Spodoptera litura } \\
\text { (Fabricius), } \\
\text { Bioassay Studies }\end{array}$ \\
\hline Article Info \\
\hline $\begin{array}{l}\text { Accepted: } \\
\text { 14 June } 2020 \\
\text { Available Online: } \\
\text { 10 July } 2020\end{array}$ \\
\hline \hline
\end{tabular}

\section{Introduction}

Bioassay is defined as "the measurement of the potency of any stimulus which may be physical, chemical, biological, physiological or psychological etc. by means of the reactions which it produce in the living organism" (Finney, 1952). Bioassay helps in ascertaining the potency and relative toxicity of different insecticides. The bioassay methods commonly employed to insect toxicity evaluations are topical application by Potter's tower, injection method, leaf dip, contact or residue film method etc. The $\mathrm{LC}_{50}$ values serve as a ready reckoner for the selection of insecticides to work out strategy for the management of insect pest under field conditions. Also, such baseline data would provide a record for detecting resistance level of the insect pests to various insecticides at different periods.

The tobacco caterpillar, Spodopteralitura (Fabricius) (Lepidoptera: Noctuidae) is also an important polyphagous pest, infesting crops of major economic importance. It was reported to attack 112 species of plants belonging to 44 families (Moussa and Ketbey, 1960).

\section{Materials and Methods}

The present research work titled "Bioassay studies for testing toxicity of novel 
insecticides against S. litura (F.)" was carried out in the Department of Entomology, College of Agriculture, Rajendranagar, Hyderabad during the year 2018-19. The materials used for the study and methods adopted are given here under.

\section{Mass Rearing of S. litura \\ Collection of eggs/larvae}

The eggs of $S$. litura were obtained from NBAIR, Bangalore and from ICRISAT, Hyderabad whereas the larvae were collected in polythene bags containing fresh red gram leaves from Students' farm and College farm, College of Agriculture, Rajendranagar, Hyderabad and also from farmer's fields in Ranga Reddy district, Hyderabad.

\section{Rearing of $S$. litura}

The eggs obtained from NBAIR, Bangalore and from ICRISAT, Hyderabad were kept separately in plastic jars. Upon hatching, the eggs were transferred to bigger petriplates containing modified semi-synthetic diet (Ahmad and McCaffery, 1991), the ingredients of which are given in Table.1.

\section{Preparation of Insecticidal Solution}

A total of six novel insecticides were used to carry out the bioassay studies. The details of the insecticides used in the study are furnished in Table.2.

Stock solution of one per cent of $100 \mathrm{ml}$ was prepared for each insecticide by dissolving their respective formulations in distilled water.

The treatments were replicated thrice. Ten larvae of five days old ( $2^{\text {nd }}$ instar), were used for each replication. The concentrations used in the study are given in Table 2.3.

\section{Bioassay Procedure}

Topical application, residue film method and surface diet method (Paramasivam and Selvi, 2017) were followed to evaluate the toxicity of the test insecticides to the $2^{\text {nd }}$ instar larvae of S.litura.

\section{Topical application method}

Ten larvae of test insect were kept in a petri dish. The toxicant solutions were applied topically on the dorsum of second instar larvae (five days old) using Potter's tower at $760 \mathrm{~mm} \mathrm{Hg}$ column difference air pressure. One $\mathrm{ml}$ of each insecticidal formulation was used for spraying. The petriplates were allowed to dry under fan and fresh diet was given to the larvae after treatment in Petri dishes. The Petri dishes were covered with Whatman's filter paper to maintain humidity. Three replications of each treatment were maintained and mortality was recorded after 24hours.

\section{Residue film method}

In a petri dish of $5 \mathrm{~cm}$ diameter $1 \mathrm{ml}$ solution of desired concentration of insecticides was sprayed with the help of Potter's spray tower and allowed to dry under an electric fan to get residue film. Desired concentration of each insecticides were made and in each concentration ten larvae were exposed to residue film. Each treatment was replicated thrice. The mortality was recorded after 24 hours.

\section{Surface diet method}

Three $\mathrm{ml}$ of the diet was pipetted into cell well trays and allowed to cool at room temperature for approximately 1 hour. For each test insecticide, serial dilutions of formulated material (100 $\mu \mathrm{l}$ aliquots) were pipetted onto the diet surface and allowed to dry for approximately 30 minutes. Second 
instar larvae were placed into a series of cell well trays that contained different concentrations of formulated insecticides. Each treatment was replicated thrice. Then mortality was recorded after 24 hours.

\section{Analysis of the data}

The corrected mortality was calculated by subjecting the observed mortality to Abbott's (1925) formula,

Corrected mortality $(\%)=$ Test mortality $(\%)-$ Control mortality $(\%) \times 100$ 100-Control mortality

Dose mortality regressions $\left(\mathrm{LC}_{50}\right)$ were computed by probit analysis (Finney, 1971) using BIOSTAT 2006 Software.

\section{Results and Discussion}

Against $S$. litura, the $\mathrm{LC}_{50}$ values for chlorfluazuron, chlorantraniliprole, spinetoram, indoxacarb, emamectin benzoate and spinosad against S. litura were 0.0006 ,
$0.0008,0.0002,0.0003,0.0001$ and 0.0102 per cent, respectively by topical application; $0.0011,0.0011,0.0006,0.0005,0.0002$ and 0.0158 per cent, respectively by residue film method and 0.0007, 0.0008, 0.0003, 0.0003, 0.0001 and 0.0122 per cent, respectively by surface diet method of bioassay. Thus from these studies it was inferred that all the insecticides tested viz. emamectin benzoate, spinetoram, indoxacarb, chlorfluazuron, chlorantraniliprole showed greater toxicity against $S$. litura compared to spinosad in all the three methods of application.

However, spinosad was relatively more toxic against $S$. litura by topical application. Efficacy of insecticides based on different methods of application against S.liturais given in Table.4.

In conclusion against $S$. litura, emamectin benzoate, spinetoram, indoxacarb, chlorfluazuron, chlorantraniliprole showed greater toxicity while spinosad was less toxic.

Table.1 Diet composition for S. litura

\begin{tabular}{|l|l|l|}
\hline Sl. No & Ingredients & Quantity \\
\hline $\mathbf{1}$ & Chickpea flour & $160 \mathrm{~g}$ \\
\hline $\mathbf{2}$ & Wheat germ & $60 \mathrm{~g}$ \\
\hline $\mathbf{3}$ & Sorbic acid & $1.7 \mathrm{~g}$ \\
\hline $\mathbf{4}$ & Dried yeast & $53 \mathrm{~g}$ \\
\hline $\mathbf{5}$ & L- Ascorbic acid & $5.3 \mathrm{~g}$ \\
\hline $\mathbf{6}$ & Methyl paraben & $3.3 \mathrm{~g}$ \\
\hline $\mathbf{7}$ & Agar- agar & $20 \mathrm{~g}$ \\
\hline $\mathbf{8}$ & Formaldehyde $10 \%$ & $14 \mathrm{ml}$ \\
\hline $\mathbf{9}$ & Antimould & $2 \mathrm{ml}$ \\
\hline $\mathbf{1 0}$ & Distilled water & $1200 \mathrm{ml}$ \\
\hline
\end{tabular}


Table.2 Details of insecticides tested for relative toxicity against $S$. litura

\begin{tabular}{|c|c|c|c|c|}
\hline SI. No & Common Name & $\begin{array}{l}\text { Trade } \\
\text { Name }\end{array}$ & Formulation & Source of Supply \\
\hline 1. & Chlorfluazuron & Atabron & 5.4 EC & UPL Limited \\
\hline 2. & Chlorantraniliprole & Coragen & $18.5 \mathrm{SC}$ & $\begin{array}{l}\text { Dupont Chemicals (India) } \\
\text { Limited }\end{array}$ \\
\hline 3. & Spinetoram & Delegate & $11.7 \mathrm{SC}$ & Dow Agrosciences \\
\hline 4. & Indoxacarb & Isacarb & $14.5 \mathrm{SC}$ & $\begin{array}{l}\text { Isagro Asia Agrochemicals Pvt. } \\
\text { Ltd. }\end{array}$ \\
\hline 5. & Emamactin benzoate & Reclaim & $5 \mathrm{SG}$ & Aegis Pvt. Ltd. \\
\hline 6. & Spinosad & Tracer & $45 \mathrm{SC}$ & Dow Agrosciences \\
\hline
\end{tabular}

Table.3 Concentration of insecticides used in bioassay studies against S. litura

\begin{tabular}{|c|c|}
\hline \multicolumn{2}{|r|}{ TOPICAL APPLICATION } \\
\hline Insecticides & Concentration used \\
\hline Chlorfluazuron & $0.005,0.003,0.001,0.0007,0.0005,0.0003,0.0001$ \\
\hline Cholrantraniliprole & $0.007,0.005,0.003,0.001,0.0007,0.0005,0.0003$ \\
\hline Spinetoram & $0.003,0.001,0.0007,0.0005,0.0003,0.0001,0.00007$ \\
\hline Indoxacarb & $\begin{array}{l}0.005,0.003,0.001,0.0007,0.0005,0.0003,0.0001,0.00007 \\
0.00005\end{array}$ \\
\hline Emamectin benzoate & $0.0007,0.0005,0.0003,0.0001,0.00007,0.00005,0.00003$ \\
\hline Spinosad & $0.07,0.05,0.03,0.01,0.009,0.007,0.005,0.003$ \\
\hline \multicolumn{2}{|r|}{ RESIDUE FILM METHOD } \\
\hline Insecticides & Concentration used \\
\hline Chlorfluazuron & $0.05,0.03,0.005,0.003,0.001,0.0007,0.0005,0.0003,0.0001$ \\
\hline Cholrantraniliprole & $0.007,0.005,0.003,0.001,0.0007,0.0005,0.0003$ \\
\hline Spinetoram & $\begin{array}{l}0.05,0.03,0.01,0.003,0.001,0.0007,0.0005,0.0003,0.0001 \text {, } \\
0.00007\end{array}$ \\
\hline Indoxacarb & $\begin{array}{l}0.005,0.003,0.001,0.0007,0.0005,0.0003,0.0001,0.00007 \text {, } \\
0.00005\end{array}$ \\
\hline Emamectin benzoate & $\begin{array}{l}0.003,0.001,0.0007,0.0005,0.0003,0.0001,0.00007,0.00005 \text {, } \\
0.00003\end{array}$ \\
\hline Spinosad & $0.07,0.05,0.03,0.01,0.009,0.007,0.005,0.003$ \\
\hline \multicolumn{2}{|r|}{ SURFACE DIET METHOD } \\
\hline Insecticides & Concentration used \\
\hline Chlorfluazuron & $0.005,0.003,0.001,0.0007,0.0005,0.0003,0.0001$ \\
\hline Cholrantraniliprole & $0.007,0.005,0.003,0.001,0.0007,0.0005,0.0003$ \\
\hline Spinetoram & $0.003,0.001,0.0007,0.0005,0.0003,0.0001,0.00007$ \\
\hline Indoxacarb & $\begin{array}{l}0.005,0.003,0.001,0.0007,0.0005,0.0003,0.0001,0.00007 \\
0.00005\end{array}$ \\
\hline Emamectin benzoate & $0.0007,0.0005,0.0003,0.0001,0.00007,0.00005,0.00003$ \\
\hline Spinosad & $0.07,0.05,0.03,0.01,0.009,0.007,0.005,0.003$ \\
\hline
\end{tabular}


Table.4 Efficacy of insecticides based on different methods of application against S.litura

\begin{tabular}{|c|c|c|c|c|}
\hline \multirow[t]{2}{*}{$\begin{array}{l}\text { Sl. } \\
\text { No }\end{array}$} & \multirow[t]{2}{*}{ Insecticides } & \multicolumn{3}{|c|}{$\begin{array}{c}\mathbf{L C}_{50} \text { values }(\%) \text { in different methods of } \\
\text { application }\end{array}$} \\
\hline & & Topical application & $\begin{array}{l}\text { Residue film } \\
\text { method }\end{array}$ & $\begin{array}{l}\text { Surface diet } \\
\text { method }\end{array}$ \\
\hline 1 & Chlorfluazuron & 0.0006 & 0.0011 & 0.0007 \\
\hline 2 & Chlorantraniliprole & 0.0008 & 0.0011 & 0.0008 \\
\hline 3 & Spinetoram & 0.0002 & 0.0006 & 0.0003 \\
\hline 4 & Indoxacarb & 0.0003 & 0.0005 & 0.0003 \\
\hline 5 & $\begin{array}{l}\text { Emamectin } \\
\text { benzoate }\end{array}$ & 0.0001 & 0.0002 & 0.0001 \\
\hline 6 & Spinosad & 0.0102 & 0.0158 & 0.0122 \\
\hline
\end{tabular}

\section{References}

Abbott, W. S. 1925. A method of computing the effectiveness of an insecticide. Journal of Economic Entomology 18: 265-267.

Ahmad, M and McCaffery, A.R. 1991. Elucidation of detoxification mechanisms involved in resistance to insecticides in the third instar larvae of a field-selected strain of Heilcoverpa armigera with the use of synergists. Pesticide Biochemistry and Physiology. 41:41-52.
Finney, D.J. 1971. Probit Analysis. S. Chard and Co., New Delhi.pp333.

Moussa, M.A and Ketbey.1960. Abundance of cotton leafworm Prodenialitura in relation to host plants and their effects on biology. Bulletin of Society of Entomologia of Egypt. 44: 241-251.

Paramsivam, M and Selvi, C. 2017. Laboratory bioassay methods to access the insecticides toxicity against insect pests- A review. Journal of Entomology and Zoology studies. 5(3):1441-1445.

\section{How to cite this article:}

Sashanka Sekhar Dash, M. Lava Kumar Reddy, G. Sridevi, Bharathi N. Bhat. 2020. Bioassay Studies for Testing Toxicity of Novel Insectidies against Spodoptera litura (Fabricius.). Int.J.Curr.Microbiol.App.Sci. 9(07): 1609-1613. doi: https://doi.org/10.20546/ijcmas.2020.907.185 